\section{評議員 増田久之君御逝去}

日本内科学会評議員、秋田大学医学部内科教授，增 田久之君脳軟化症にて御療養中のところ，急性腎不 全症のため, 昭和58年 2 月 1 日午前10時50分逝去遊ば された。

告別式は秋田市八橋戊川原64, 秋田県農協ビル 9 階, 大会議室において, 秋田大学渡部美種医学部長が葬儀 委員長，また副委員長は金沢知博教授のもとに執行せ られた。

阿部 裕日本内科学会々頭より捧呈申し上げた韦辞 は内科三浦 亮教授が代讀して韦意を表しました。

御遺族宅； 秋田市広面字大巻47 増田友之様方

$$
\text { 入会 }
$$

\begin{tabular}{|c|c|}
\hline 奥野 正隆 & 岐阜大学第一内科 \\
\hline 高木 寛治 & 同上 \\
\hline 高木 昌一 & 同上 \\
\hline i十嵐 敢 & 大阪大学第三内科 \\
\hline ケ島 守 & $\begin{array}{l}\text { 杤木県河内郡南河内町薬師寺 } 3311 \text { 。 } \\
191 の 406\end{array}$ \\
\hline 均 & $\begin{array}{l}\text { 東京都大田区東雪ヶ谷 } 2 \text { の11の3 } \\
\text { 川台マンション別館 } 307 \text { 号 }\end{array}$ \\
\hline 木 幸善 & 東邦大学第二内科 \\
\hline 悟 & 東京医科大学内科地下研 \\
\hline 俊行 & 東京都世田谷区上祖師谷 2 の 17 の 12 \\
\hline 屋武有夫 & 東京都中野区大和町 4 の35の 18 \\
\hline 川 玲子 & 東京大学第二内科 \\
\hline 宏 & 同第四内科 \\
\hline 直子 & 船橋市宮本 2 の 1 の16 \\
\hline 治 & 聖マリアンナ医科大学第二内科 \\
\hline 良光 & 同上 \\
\hline
\end{tabular}

吉田 繁夫 川崎市多摩区枡形 5 の 16 の 3 の 102

瀬川 譜一 北里大学内科

坂口章相模原市鵜野森571 グリーソハイッ Dの 1304

青木 信平川崎市中原区井田川崎市立井田病院 内科

伊藤隆旭市1の1326 旭中央病院内科

田中秀雄同上

香井克彦 府中市片町 107011

青沼 宏深 三重大学第一内科

服部 正大同上

安田正樹同上

山室匡史同上

严川潤一郎 今治市南高下町 305019 第三藤原 マンション 3 の 3

\section{訂正(追記)}

日本内科学会雑誌 第72巻第 1 号（昭和58年 1 月 10 日） 70 貢揭載 臨床「房室伝導障害を伴つたWerner症 倨群の 1 症例，群馬大学医学部第二内科藤江正雄他 7 名」論文は，

〔昭和56年5月9日 第310回関東地方会推萀〕でした。

また，第72巻第 2 号（昭和58年 2 月10日）

173頁, 左側下 1 行 $\cdots .80$ 項目以上

173頁, 右側下 1 行 …肺癌の順に多く

の太字部分が脱落しました。

このことを追記致します。
日本内科学会雑誌 第72卷 第 3 号

昭和58年 3 月 6 日印刷・昭和58年 3 月 10 日発行

購読料年額 9,000 円也（会費）郵送料共 T113 東京都文京本郷 3 丁目 34 番 3 号 発行所社団法人日本内科学会 振替東京 2-6232番・電話 (03) 813-5991～2番
編集人 東京都沾谷区東 $1 丁$ 目26番30号

阿部正和

発行人 東京都三鷹市上連雀 4 丁目 4 番13号 大 國 岩 太 郎

印刷人東京都北区西ヶ原 3 丁目46番10号 向喜 代 次

印刷所東京都北区西ヶ原 3 丁目46番10号 株式会社 杏 林 舎

原著・臨本論文揭载者の内，氏名右肩にの印がある人は共同著作物（論文）の著作者人格権を行使されらる，実質 的の代表責任者とみなされる人である。

本雑誌に揭載された論文のらち，その題名，所属，発表者名，概要，内科学会地方会抄録に限つて，著者ならびに 本会の許可を党なくても複写することができる，たざし，党利を目的としない場合に限る. 